\title{
Targeting Prostate Cancer Cells In Vivo Using a Rapidly Internalizing Novel Human Single-Chain Antibody Fragment
}

\author{
Jiang He $\mathrm{He}^{1,2}$, Yong Wang ${ }^{3}$, Jinjin Feng ${ }^{1}$, Xiaodong Zhu ${ }^{3}$, Xiaoli Lan ${ }^{1}$, Arun K. Iyer ${ }^{1}$, Niu Zhang ${ }^{3}$, Youngho Seo ${ }^{1}$, \\ Henry F. VanBrocklin ${ }^{1,2}$, and Bin Liu ${ }^{2,3}$ \\ ${ }^{1}$ Department of Radiology and Biomedical Imaging, Center for Molecular and Functional Imaging, University of California at San \\ Francisco, San Francisco, California; ${ }^{2}$ Helen Diller Family Comprehensive Cancer Center, University of California at San \\ Francisco, San Francisco, California; and ${ }^{3}$ Department of Anesthesia, University of California at San Francisco, \\ San Francisco, California
}

Human antibodies targeting prostate cancer cell surface epitopes may be useful for imaging and therapy. The objective of this study was to evaluate the tumor targeting of an internalizing human antibody fragment, a small-size platform, to provide high contrast in a mouse model of human prostate carcinoma. Methods: A prostate tumor-targeting single-chain antibody fragment (scFv), UA20, along with a nonbinding control scFv, N3M2, were labeled with ${ }^{99 m T c}$ and evaluated for binding and rapid internalization into human prostate tumor cells in vitro and tumor homing in vivo using xenograft models. For the in vitro studies, the labeled UA20 scFv was incubated at $37^{\circ} \mathrm{C}$ for $1 \mathrm{~h}$ with metastatic prostate cancer cells (DU145) to assess the total cellular uptake versus intracellular uptake. For the animal studies, labeled UA20 and N3M2 scFvs were administered to athymic mice implanted subcutaneously with DU145 cells. Mice were imaged with small-animal SPECT/CT with concomitant biodistribution at 1 and $3 \mathrm{~h}$ after injection. Results: The UA20 scFv was labeled in $55 \%-65 \%$ yield and remained stable in phosphate buffer within $24 \mathrm{~h}$. The labeled UA20 scFv was taken up specifically by prostate tumor cells. Internalization was rapid, because incubation at $37^{\circ} \mathrm{C}$ for less than $1 \mathrm{~h}$ resulted in $93 \%$ internalization of total cell-associated scFvs. In animal studies, SPECT/ CT showed significant tumor uptake as early as $1 \mathrm{~h}$ after injection. At $3 \mathrm{~h}$ after injection, tumor uptake was 4.4 percentage injected dose per gram (\%ID/g), significantly greater than all organs or tissues studied (liver, $2.7 \% \mathrm{ID} / \mathrm{g}$; other organs or tissues, $<1 \% \mathrm{ID} / \mathrm{g})$, except the kidneys $(81.4 \% \mathrm{ID} / \mathrm{g})$, giving tumor-toblood and tumor-to-muscle ratios of $12: 1$ and $70: 1$, respectively. In contrast, the control antibody exhibited a tumor uptake of only $0.26 \% \mathrm{ID} / \mathrm{g}$, similar to that of muscle and fat. Tumor-specific targeting was evidenced by reduced tumor uptake of nearly $70 \%$ on administration of a 10-fold excess of unlabeled UA20 scFv. Kidney uptake was nonspecific, consistent with the route of excretion by scFvs. Conclusion: The UA20 scFv showed rapid and

Received Oct. 19, 2009; revision accepted Dec. 9, 2009.

For correspondence or reprints contact either of the following: Jiang $\mathrm{He}$, Department of Radiology and Biomedical Imaging, Center for Molecular and Functional Imaging, University of California at San

Francisco, 185 Berry St., Suite 350, San Francisco, CA 94143.

E-mail: Jiang.He@radiology.ucsf.edu

Bin Liu, Department of Anesthesia, University of California at San

Francisco, 1001 Potrero Ave., 3C38, San Francisco, CA 94110.

E-mail: liub@anesthesia.ucsf.edu

COPYRIGHT $\odot 2010$ by the Society of Nuclear Medicine, Inc. specific internalization in prostate tumor cells in vitro and accumulation in prostate tumor xenografts in vivo, demonstrating the potential for future development for prostate cancer imaging and targeted therapy.

Key Words: molecular imaging; prostate cancer; antibody fragment

J Nucl Med 2010; 51:427-432

DOI: 10.2967/jnumed.109.069492

$\mathbf{P}_{\mathrm{r}}$ rostate cancer is the second leading cause of mortality and morbidity in American men. Current methods including a prostate-specific antigen test and imaging technology for detecting prostate cancer are limited, leaving most early malignancies undiagnosed and sites of metastasis in advanced disease undetected $(1,2)$. Major deficiencies also exist in the treatment of prostate cancer, especially metastatic disease. To improve the detection and therapy of prostate cancer, targeting ligands that selectively home to prostate cancer cells but not normal cells are needed.

Prostate-specific membrane antigen (PSMA), an established biomarker for prostate cancer, has been the focus of various efforts to develop probes for use in the diagnosis and therapy of prostate cancer, including small-molecule inhibitors, peptides, and antibodies (3-9). Particularly, a variety of low-molecular-weight PSMA inhibitors, ureabased inhibitors, and near-infrared dye-conjugated phosphinate inhibitors have been used for the in vivo imaging of human prostate cancer xenografts in athymic nude mice (10-14). However, urea-based compounds are rapidly reversible inhibitors of PSMA. Current prostate tumor imaging agents based on small-molecule inhibitors of PSMA show promise but require further optimization with regard to pharmacokinetics, especially rapid renal clearance (11).

There have been extensive efforts to develop monoclonal antibody imaging and therapeutic agents against prostate 
cancer. Several anti-PSMA monoclonal antibodies have been developed and used (15-18). One murine antibody that targets PSMA, ProstaScint (capromab pendetide; Cytogen/EUSA), has been approved by the Food and Drug Administration as a diagnostic imaging agent for pelvic lymph node spread in newly diagnosed patients with biopsy-proven prostate cancer and for recurrence in postprostatectomy patients. Capromab pendetide is not approved for detecting bone metastasis. The mechanism of capromab pendetide accumulation is less than straightforward because this murine antibody targets an intracellular epitope of PSMA. Over the years, there have been efforts to develop monoclonal antibodies that recognize additional prostate cancer antigens. Recent examples include antibodies against prostate stem cell antigen by Reiter's group (discussed in Lam et al. (19)) and Wu's group (discussed in Olafsen et al. $(20,21)$ and Leyton et al. $(22,23))$ and novel antigens such as mindin/RG-1 (24,25). Although high affinity is an important variable of a useful antibody-based imaging agent, affinity alone is insufficient in selecting antibodies with superior imaging and in vivo targeting functions. It has been shown that monoclonal antibodies with high affinity may impair efficient tumor penetration and reduce uptake efficiency in vivo (26). Biodistribution studies with single-chain antibody fragments (scFvs) against HER2-expressing SK-OV-3 xenografts demonstrated that quantitative tumor retention did not increase with enhancements in affinity beyond $10^{-9} \mathrm{M}(26)$.

In addition to high affinity to an extracellular epitope, other variables such as internalization and clearance play significant roles in modulating the efficiency of tumor accumulation of antibodies in vivo. We have recently combined phage antibody library selection with lasercapture microdissection to identify internalizing human scFvs that bind to prostate tumor cells in situ (27). A panel of human scFvs have been identified that possess properties that the selection was designed to capture (27): binding to prostate tumor cell lines including hormone-refractory metastatic lines, binding to prostate tumor cells in situ, and binding to internalizing epitopes and thereby the ability to mediate intracellular delivery of small-molecule payloads to tumor cells (28). These scFvs thus recognize clinically represented tumor cell surface antigens and offer the potential to deliver high levels of imaging probes to tumor cells but not normal tissues based on intracellular delivery strategies. The present study investigated the tumor-targeting potential of one of these rapidly internalizing scFvs.

\section{MATERIALS AND METHODS}

\section{Expression and Purification of Prostate \\ Tumor-Targeting scFv}

The $\mathrm{scFv}$ gene was subcloned from the phage vector into the secretion vector pUC119mycHis, resulting in the addition of a c-myc epitope and a hexahistidine tag at the $\mathrm{COOH}$ terminus of the $\mathrm{scFv}$. scFv protein was harvested from the bacterial periplasm and purified by immobilized metal affinity chromatography and gel filtration (28-32). After overnight dialysis in phosphatebuffered saline, antibody purity was determined by gel electrophoresis, and concentration was determined using NanoDrop (NanoDrop Products/Thermo Scientific).

Preparation of $\left.{ }^{99 m} \mathrm{Tc}(\mathrm{CO})_{3}\left(\mathrm{OH}_{2}\right)_{3}\right]^{+}$. The precursor $\left[{ }^{99 \mathrm{~m}} \mathrm{Tc}(\mathrm{CO})_{3}\left(\mathrm{OH}_{2}\right)_{3}\right]^{+}$was formed quantitatively by carbonylation of the ${ }^{99} \mathrm{mcO}_{4}{ }^{-}$in 1 step. The carbonyl kit (IsoLink; Tyco/ Mallinckrodt) was used to prepare the $\left[{ }^{99 \mathrm{~m}} \mathrm{Tc}(\mathrm{CO})_{3}\right]$ moiety. A 10$\mathrm{mL}$ penicillin vial containing potassium boranocarbonate $(8.5 \mathrm{mg}$, $63 \mu \mathrm{mol})$, sodium tetraborate $10 \mathrm{H}_{2} \mathrm{O}(2.9 \mathrm{mg}, 8.0 \mu \mathrm{mol})$, Natartrate $2 \mathrm{H}_{2} \mathrm{O}(15.0 \mathrm{mg}, 53 \mu \mathrm{mol})$, and $\mathrm{Na}_{2} \mathrm{CO}_{3}(4.0 \mathrm{mg}, 38 \mu \mathrm{mol})$ was fitted with a rubber septum and the vial flushed with $\mathrm{N}_{2}$ gas for $15 \mathrm{~min} .{ }^{99 \mathrm{~m}} \mathrm{Tc}$-generator eluant (370-740 MBq [10-20 mCi]) in $1,000 \mu \mathrm{L}$ of saline was added by a syringe, and the solution was heated to $100^{\circ} \mathrm{C}$ for $30 \mathrm{~min}$. After cooling on an ice bath, the alkaline solution was neutralized to final $\mathrm{pH} 6.0-6.5$ by the addition of 180-200 $\mu \mathrm{L}$ of $1 \mathrm{M} \mathrm{HCl}$. Quality control was performed by gradient high-performance liquid chromatography and C-18 Sep-Pak cartridge column (Waters Corp.).

Antibody Radiolabeling. An aliquot $(20-50 \mu \mathrm{L})$ of scFvs (UA20 or control N3M2, $2 \mathrm{mg} / \mathrm{mL}$ ) was mixed with $100-500$ $\mu \mathrm{L}$ of $\left[{ }^{99 \mathrm{~m}} \mathrm{Tc}(\mathrm{CO})_{3}\left(\mathrm{OH}_{2}\right)_{3}\right]^{+}$solution, and the mixture was heated at $37^{\circ} \mathrm{C}$ for $60 \mathrm{~min}$. The reaction mixture was cooled down to room temperature and the product isolated using a PD-10 gelfiltration column (GE Healthcare) eluted with phosphate-buffered saline ( $\mathrm{pH}$ 7.2) as described previously (33). Both size-exclusion high-performance liquid chromatography and thin-layer chromatography analyses were used to characterize the labeled scFvs.

\section{In Vitro Cell Culture Assay}

The internalization experiments were performed as described previously (27,28). Briefly, 1 million DU145 cells were seeded per well and incubated in RMPI 1640 medium containing $10 \%$ fetal bovine serum at $37^{\circ} \mathrm{C}$ for $3 \mathrm{~h}$. Approximately $150 \mathrm{kBq}$ of ${ }^{99 \mathrm{~m}} \mathrm{Tc}-$ labeled $\mathrm{scFv}$ in a final concentration of $5 \mathrm{nmol} / \mathrm{L}$ were added to the medium, and the cells were incubated at $37^{\circ} \mathrm{C}$ in $5 \% \mathrm{CO}_{2}$ for various times. The cells were washed twice with phosphatebuffered saline $(\mathrm{pH}$ 7.2) and then washed twice with glycine buffer $(0.05 \mathrm{~mol} / \mathrm{L}$ of glycine solution, $150 \mathrm{mmol} / \mathrm{L}$ of $\mathrm{NaCl}$, pH-adjusted to 2.8 with $1 \mathrm{~N} \mathrm{HCl}$ ) to distinguish between cell surface-bound (acid-releasable) and internalized (acid-resistant) radioligand. Finally, cells were lysed with $1 \mathrm{~N} \mathrm{NaOH}$ at $37^{\circ} \mathrm{C}$ for $10 \mathrm{~min}$. The radioactivity was measured on a $\gamma$-counter and expressed as the percentage of applied activity normalized to 1 million cells. As a control for surface stripping, the experiment was performed in parallel at $4^{\circ} \mathrm{C}$ to determine the fraction removed by glycine wash. The data were used to calculate the efficiency of surface stripping to normalize results obtained from experiments done at $37^{\circ} \mathrm{C}$. As a control for nonspecific uptake, the experiment was repeated with the addition of a 10-fold excess of cold scFv.

\section{Animal Studies}

Animal procedures were performed according to a protocol approved by the University of California San Francisco Institutional Animal Care and Use Committee.

\section{Xenograft Model}

Six-week-old male $n u / n u$ mice were purchased from Charles River Laboratories. For tumor inoculation, $1 \times 10^{6}$ DU145 cells in $100 \mu \mathrm{L}$ of phosphate-buffered saline were administered sub- 
cutaneously to seed xenograft tumors in one or both flanks of the animal. Growing tumors were palpated, and the diameters were measured by calipers. The experiment started when the tumor reached $3-5 \mathrm{~mm}$ in diameter.

\section{Biodistribution Studies}

Tumor-bearing nude mice in groups of 4 animals were injected with $18.5-37.0 \mathrm{MBq}(0.5-1.0 \mathrm{mCi})$ of ${ }^{99 \mathrm{~m}}$ Tc-labeled UA20 (5-10 $\mu \mathrm{g}$ of UA20) or the control nonbinding N3M2 scFv. The mice were euthanized and dissected at 1 and $3 \mathrm{~h}$ after injection of labeled antibodies. Blood, tumor, and major organ specimens were collected and weighed. The radioactivity in the tissues was measured against known activity standards using a $\gamma$-counter (Wizard; Perkin Elmer). The percentage injected dose per gram (\%ID/g) was determined. Tumor-targeting specificity was evaluated in 1 group (blocking group) by the administration of a 10-fold excess of unlabeled UA20 $1 \mathrm{~h}$ before the administration of ${ }^{99 \mathrm{~m}} \mathrm{Tc}-$ labeled UA20.

\section{SPECT/CT}

Mice were imaged with a dedicated small-animal SPECT/CT system (X-SPECT; Gamma Medica Ideas, Inc.). For anatomic correlation, small-animal CT was performed after the intravenous injection of $18.5-37.0 \mathrm{MBq}$ of ${ }^{99 m} \mathrm{Tc}-\mathrm{UA} 20$. The mouse was placed on the bed and positioned in front of a 2.0-mm-diameter pinhole collimator. The spatial resolution and sensitivity of the pinhole SPECT system have been characterized from phantom studies, and for this imaging geometry, the system spatial resolution was $1.1 \mathrm{~mm}$, with a sensitivity of 4,600 counts $/ \mathrm{min} /$ $\mathrm{MBq}(170$ counts $/ \mathrm{min} / \mu \mathrm{Ci})$. A planar image of the line source attached to the holder was acquired for postacquisition correction of misalignment error. SPECT scans were obtained at 1 and $3 \mathrm{~h}$ after injection of the radiolabeled antibody, and 64 projection views were acquired over a $360^{\circ}$ rotation in a $256 \times 256$ matrix. The acquisition time was $20-60 \mathrm{~min}$.

\section{Statistical Analysis}

All quantitative data are reported as mean \pm SD. Statistical analysis was performed using a 2-tailed $t$ test; data differences were considered statistically significant for $P$ values of 0.05 or less.

\section{RESULTS}

In Vitro Characterization of ${ }^{99 m}$ Tc-Labeled UA20

The UA20 $\mathrm{scF} v$ was radiolabeled with ${ }^{99 \mathrm{~m} T c}$ and investigated for cell binding and internalization in vitro using the prostate cancer cell line DU145. The ${ }^{99 \mathrm{~m}} \mathrm{Tc}-\mathrm{labeling}$ yield from $\left[{ }^{99 \mathrm{~m}} \mathrm{Tc}(\mathrm{CO})_{3}\left(\mathrm{OH}_{2}\right)_{3}\right]^{+}$was $55 \%-65 \%$ at the described condition. The radiochemical purity of the final radiolabeled scFvs after purification was greater than $95 \%$, and the specific activity was $7.4 \mathrm{MBq} / \mu \mathrm{g}\left(5 \times 10^{5} \mathrm{Ci} / \mathrm{mol}\right)$. The labeling of $\mathrm{scFv}$ by complexing ${ }^{99 \mathrm{~m} \mathrm{Tc}}$ with the hexahistidine tag, as previously reported (32), was stable as confirmed in phosphate buffer for $24 \mathrm{~h}$.

The binding affinity of ${ }^{99 \mathrm{~m}}$ Tc-labeled UA20 was also measured by incubating DU145 cells with increasing concentrations (between 0.5 and $100 \mathrm{nM}$ ) of UA20 at $4^{\circ} \mathrm{C}$, showing a dissociation constant of $5.5 \mathrm{nM}$ (Fig. 1A). Labeled UA20 was rapidly internalized on binding to the tumor cell surface, with $93 \%$ of total cell accumulation due to internalization at $37^{\circ} \mathrm{C}$ within the first hour of incubation. The observed binding was specific because it was inhibited by an excess of unlabeled UA20 (Fig. 2), which showed only about $6 \%$ cell-associated activity, much lower than the study groups $(P<0.01)$. Although we did not perform the Lindmo assay (34) to determine whether $100 \%$ of our antibodies were active, these results nonetheless demonstrate that the UA20 scFv binds with high affinity to prostate tumor antigen and that the site-specific labeling of UA20 scFv with ${ }^{99 \mathrm{~m}} \mathrm{Tc}$ through the hexahistidine tag had not significantly compromised its binding affinity.

\section{Biodistribution of ${ }^{99 m}$ Tc-Labeled UA20 scFv and Small-Animal SPECT/CT}

UA20 and control N3M2 scFvs were labeled with ${ }^{99 \mathrm{~m}} \mathrm{Tc}$ and investigated for in vivo prostate tumor-targeting in DU145 xenograft models. The labeled UA20 and control scFvs were administered to athymic mice implanted sub-
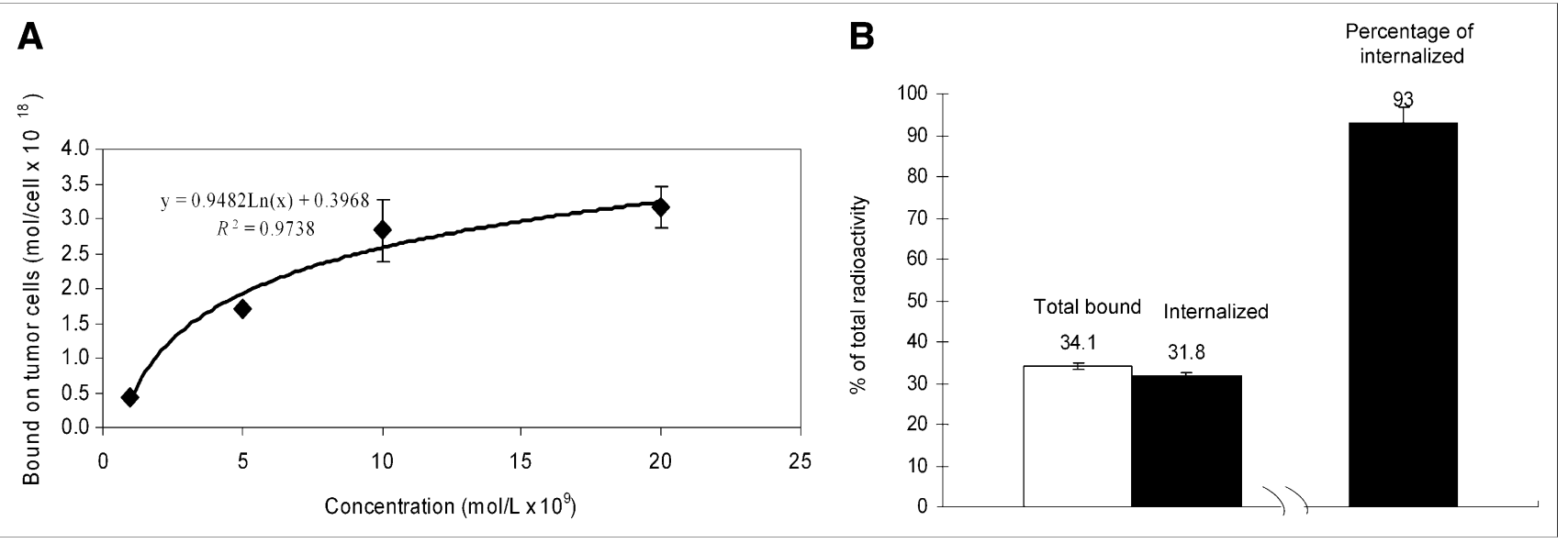

FIGURE 1. Cell binding and internalization of 99mTc-labeled UA20. (A) Binding curves of 99mTc-labeled UA20. Varying concentrations of antibodies were incubated with prostate cancer cell line DU145 at $4^{\circ} \mathrm{C}$ for $1 \mathrm{~h}$, and number of cell-associated antibody molecules is plotted. (B) Internalization of $99 \mathrm{mTc}$-labeled UA20 after $1 \mathrm{~h}$ of incubation with prostate cancer cell line DU145 at $37^{\circ} \mathrm{C}$. Percentage internalization is calculated from internalized amount over total bound amount. 


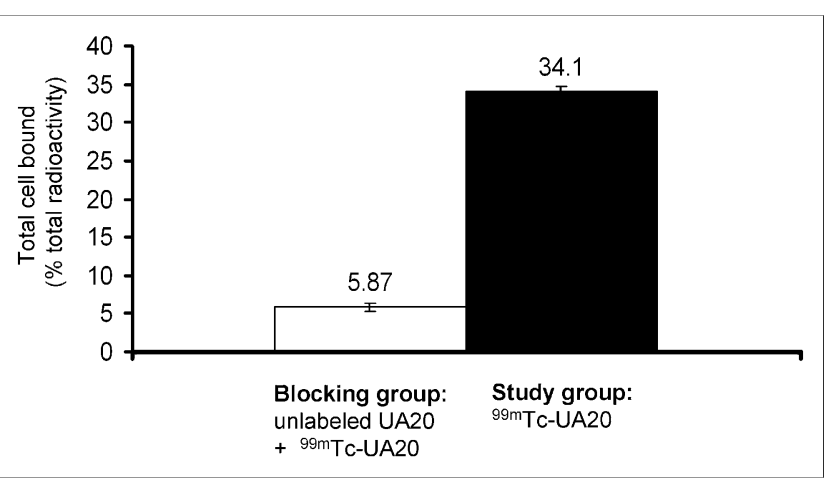

FIGURE 2. Specificity of ScFv internalization. Ten-fold excess of cold UA20 scFv was mixed with $99 \mathrm{mT}$ Tc-labeled UA20 scFv and incubated with DU145 cells at $37^{\circ} \mathrm{C}$ for $1 \mathrm{~h}$.

cutaneously with DU145 cells. Mice were imaged with small-animal SPECT/CT and sacrificed at 1 and $3 \mathrm{~h}$ after injection to assess biodistribution. As shown in Table 1 and Figure $3,{ }^{99 \mathrm{~m}} \mathrm{Tc}-\mathrm{UA} 20$ was rapidly distributed and reached low levels in the blood and all normal organs or tissues studied, except the kidneys, giving a remarkably high tumor-to-blood ratio of 12:1 and tumor-to-muscle ratio of 70:1 as early as $3 \mathrm{~h}$ after injection. Small-animal SPECT/ CT showed strong tumor accumulation (Figs. 4A and 4C). The tumor was visualized as early as $1 \mathrm{~h}$ after injection. At $3 \mathrm{~h}$ after injection, tumor uptake was $4.4 \% \mathrm{ID} / \mathrm{g}$, liver uptake was $2.7 \% \mathrm{ID} / \mathrm{g}$, and kidney uptake was $81.4 \% \mathrm{ID} / \mathrm{g}$. The remaining organ or tissue uptakes were lower than $1 \% \mathrm{ID} / \mathrm{g}$. In contrast, the control N3M2 scFv exhibited a tumor uptake of only $0.26 \% \mathrm{ID} / \mathrm{g}$, significantly lower than UA20 $(P<0.01)$, similar to muscle and fat, and much lower than most other organ or tissues. Kidney uptake of the control N3M2 scFv was $81.5 \% \mathrm{ID} / \mathrm{g}$, similar to that of the UA20 $\mathrm{scFv}$ and consistent with the route of $\mathrm{scFv}$ clearance in vivo.

The in vivo tumor targeting of ${ }^{99 \mathrm{~m}} \mathrm{Tc}-$ labeled UA20 scFv at both tumor sites (Fig. 4B) was successively blocked by the administration of a 10 -fold excess of nonradiolabeled $\mathrm{UA} 20 \mathrm{scFv}$ at $1 \mathrm{~h}$ before injection of ${ }^{99 \mathrm{~m} T c}$-labeled UA20 $\mathrm{scFv}$, with tumor uptake decreasing by about $70 \%$, further demonstrating the in vivo targeting specificity of the UA20 scFv $(P<0.02)$.

\section{DISCUSSION}

We report here the in vivo tumor targeting of a novel internalizing $\mathrm{scFv}$ (UA20) in human prostate cancer xenografts in nude mice. This fully human antibody fragment was originally identified by selecting a phage antibody display library on prostate tumor tissue specimens using a laser-capture microdissection-based strategy that enriched scFvs targeting internalizing epitopes present on prostate tumor cells in situ and metastatic prostate cancer cell lines. In vitro studies have demonstrated that this UA20 scFv is taken up specifically by targeted prostate tumor cells but not the control nontumorigenic cells (27). Successful validation of the in vivo tumor-targeting function of this antibody in a human prostate cancer xenograft mouse model would facilitate its translational development for potential clinical applications.

Several important findings have been uncovered by this study. First, the UA20 scFv showed a strikingly rapid internalizing activity in vitro and efficient tumor targeting in vivo. In cell culture studies, over $90 \%$ of the total cellbound UA20 was internalized within $1 \mathrm{~h}$ after incubation at $37^{\circ} \mathrm{C}$. For in vivo studies, the UA20 scFv was rapidly cleared from blood and accumulated in tumor in significant amounts at $1 \mathrm{~h}$ after injection. Rapid clearance was seen for

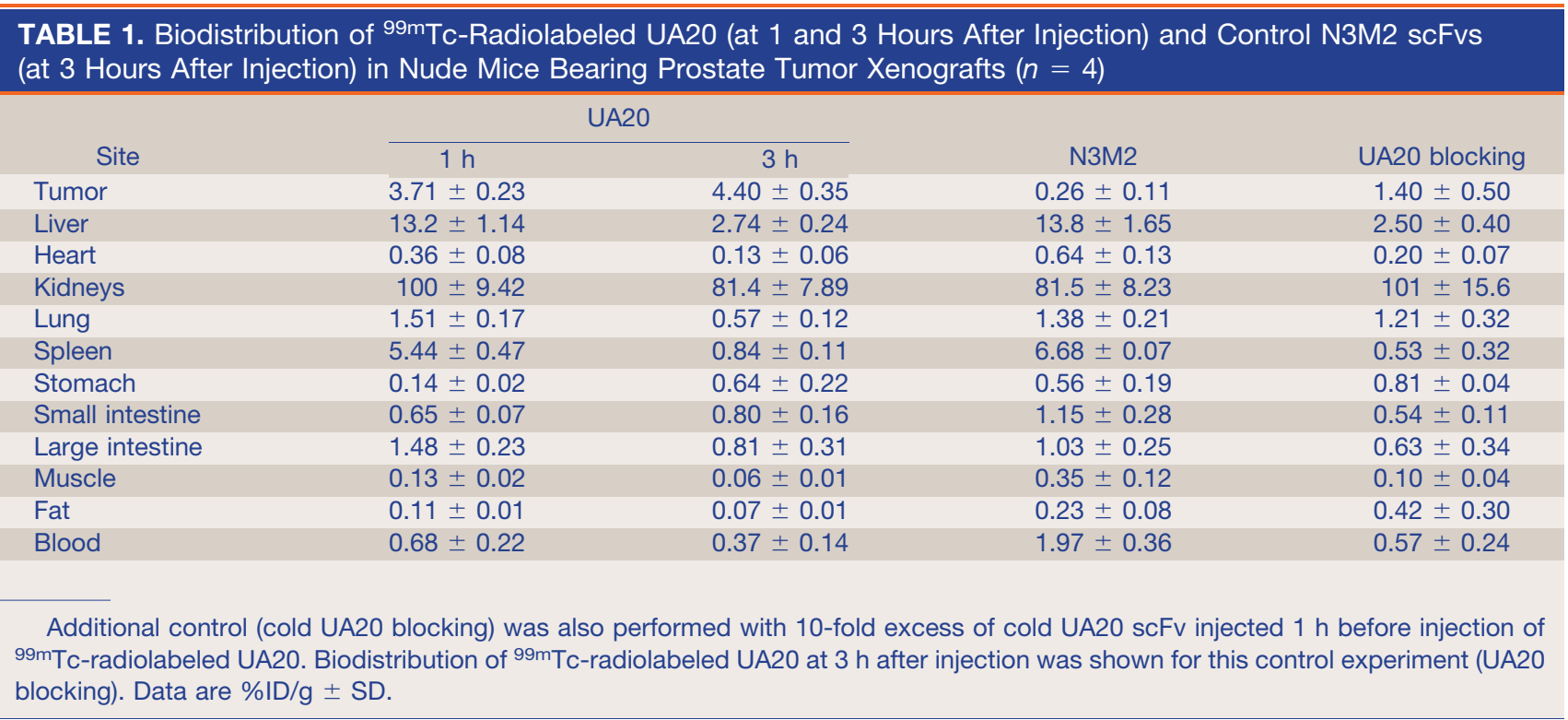




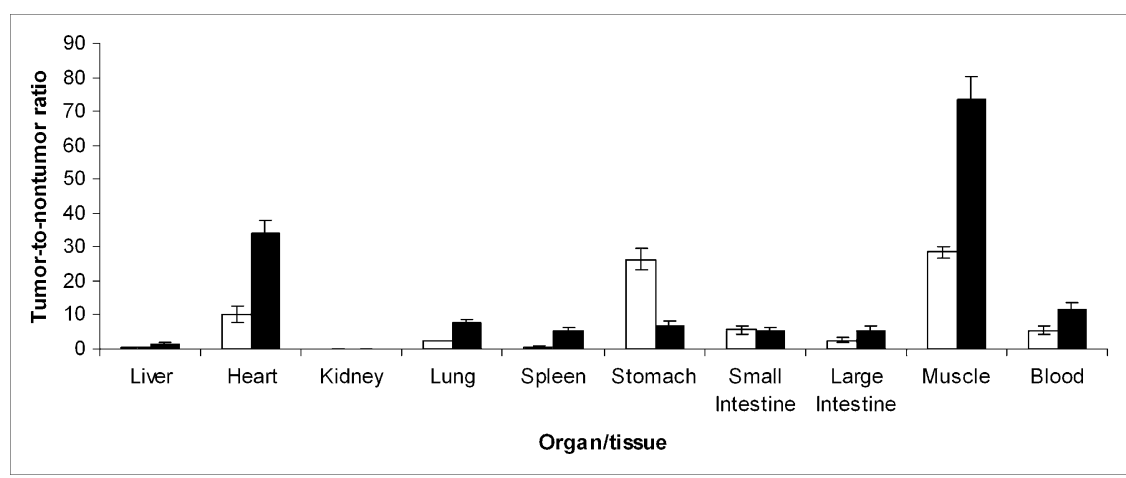

FIGURE 3. Tumor-to-nontumor ratio of $99 \mathrm{mTc}$-labeled UA20 in prostate cancer xenograft mice at $1(\square)$ and $3 \mathrm{~h} \mathrm{( \square )}$ after injection. Ratio is determined by dividing tumor uptake $(\% \mathrm{ID} / \mathrm{g})$ by nontumor uptake in each individual mouse and averaging ( $n=4$ in each group). all normal organs except the kidneys (the site of $\mathrm{scFV}$ excretion). The rapid clearance and efficient tumor targeting make it feasible in the future to label the UA20 scFv with positron-emitting residualizing radiometal isotopes with short half-lives such as ${ }^{68} \mathrm{Ga}$ for PET. Second, there is a remarkable time-dependent increase in target-to-nontarget ratio. For example, the tumor-to-muscle ratio increased from 20 at $1 \mathrm{~h}$ after injection to 70 at $3 \mathrm{~h}$ after injection. Likewise, the tumor-to-blood ratio increased from 5 at $1 \mathrm{~h}$ after injection to 12 at $3 \mathrm{~h}$ after injection. Therefore, for this UA20 scFv, there is a temporal amplification of the difference between tumor and nontarget organs or tissues, which may be exploited for enhancing contrast for imaging and therapeutic strategies.

Both the UA20 and the control N3M2 scFvs have a high uptake at the kidney, consistent with the route of $\mathrm{scFv}$ clearance in the body. Alternatively, this high uptake may be attributed in part to the histidine bidentate chelator (32). In any case, additional engineering of the UA20 scFv or modification of radiolabeling strategies may further in-
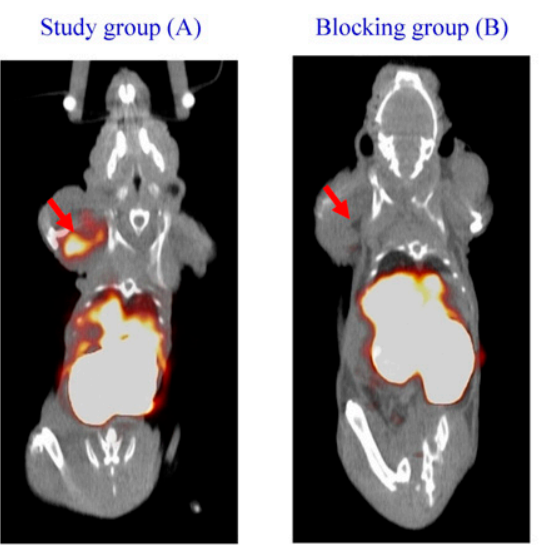

Study group (C)

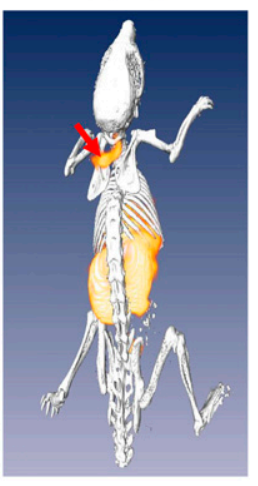

FIGURE 4. Small-animal SPECT/CT of nude mice bearing DU145 xenograft at front flank. (A) Image taken at $3 \mathrm{~h}$ after

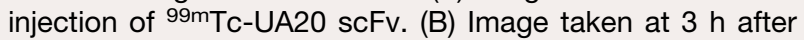
injection of ${ }^{99 m} \mathrm{Tc}$-labeled UA20 scFv. In this experiment, 10 -fold excess of unlabeled UA20 scFv was injected $1 \mathrm{~h}$ before injection of ${ }^{99 \mathrm{mTc}} \mathrm{Tc}-\mathrm{UA} 20 \mathrm{scFv}$. (C) Representative image of 3-dimensional rendering of tumor targeting by 99mTc-labeled UA20 scFv. crease the kidney clearance rate and reduce the background activity. Finally, developing other forms such as diabody, minibody, or Affibody (Affibody $\mathrm{AB}$ ) could further improve the tumor binding and homing efficiency and overall molecular pharmacokinetics $(20,33,35,36)$.

Immunohistochemistry studies have shown that the UA20 antibody binds to prostate tumors but not a panel of normal tissues studied (27) including the kidneys, heart, brain, lungs, liver, and colon. The apparent cell surface density of the antigen bound by the UA20 antibody, as measured by cell-binding assay, was about $2.7 \times 10^{6}$ receptors per cell (He and Liu, unpublished data, 2009). We are currently identifying the tumor antigen targeted by the UA20 antibody by a novel expression-cloning approach that we have developed on the basis of yeast surface human cDNA display (37-39) and by direct immunoprecipitation and mass spectrometry analysis (40). Identification of the UA20 antigen could provide an entry point to further study prostate tumor development, including metastases; allow additional studies on tissue distribution; and further optimize lead antibodies to improve affinity and internalization kinetics.

\section{CONCLUSION}

A novel human scFv (UA20), which was previously identified by selecting a phage antibody display library on human prostate cancer tissues by laser-capture microdissection, has been successfully radiolabeled with ${ }^{99 \mathrm{~m}} \mathrm{Tc}$ using a single amino acid chelate-tricarbonyl strategy. The labeled $\mathrm{scFv}$ showed rapid internalization in vitro and efficient tumor targeting in vivo in the human prostate cancer cell xenografts, demonstrating potential use in targeted imaging and therapy development.

\section{ACKNOWLEDGMENTS}

We thank Dr. Mary E. Dyszlewski at Tyco/Mallinckrodt for providing the carbonyl kit (IsoLink). This work is supported by NIH R01 CA135358, R01 CA118919, and R21 CA137429 and the American Cancer Society (IRG-97150-10). 


\section{REFERENCES}

1. Ravizzini G, Turkbey B, Kurdziel K, Choyke PL. New horizons in prostate cancer imaging. Eur J Radiol. 2009;70:212-226.

2. Bander NH. Technology insight: monoclonal antibody imaging of prostate cancer. Nat Clin Pract Urol. 2006;3:216-225.

3. Sodee DB, Ellis RJ, Samuels MA. Prostate cancer and prostate bed SPECT imaging with ProstaScint: semiquantitative correlation with prostatic biopsy results. Prostate. 1998;37:140-148.

4. Milowsky MI, Nanus DM, Kostakoglu L. Vascular targeted therapy with antiprostate-specific membrane antigen monoclonal antibody J591 in advanced solid tumors. J Clin Oncol. 2007;25:540-547.

5. Zhou J, Neale JH, Pomper MG, Kozikowski AP. NAAG peptidase inhibitors and their potential for diagnosis and therapy. Natl Rev Drug Discov. 2005;4: 1015-1026.

6. Misra P, Valerie H, Pannier N, Maison W, Frangioni JV. Production of multimeric prostate-specific membrane antigen small-molecule radiotracers using a solid-phase ${ }^{99 m}$ Tc preloading strategy. J Nucl Med. 2007;48:1379-1389.

7. Tang H, Brown M, Ye Y. Prostate targeting ligands based on $N$-acetylated $\alpha$-linked acidic dipeptidase. Biochem Biophys Res Commun. 2003;307:8-14

8. Humblet V, Lapidus R, Williams L. High-affinity near-infrared fluorescent small-molecule contrast agents for in vivo imaging of prostate-specific membrane antigen. Mol Imaging. 2005;4:448-462.

9. Liu T, Wu L, Kazak M, Berkman CE. Cell-surface labeling and internalization by a fluorescent inhibitor of prostate-specific membrane antigen. Prostate. 2008;68:955-964.

10. Mease RC, Dusich CL, Foss CA, et al. $N$-[N-[(S)-1,3-dicarboxypropyl $]$ carbamoyl]-4-[ $\left[{ }^{18} \mathrm{~F}\right]$ fluorobenzyl-L-cysteine, $\left[{ }^{18} \mathrm{~F}\right] \mathrm{DCFBC}$ : a new imaging probe for prostate cancer. Clin Cancer Res. 2008;14:3036-3043.

11. Banerjee SR, Foss AC, Castanares M. Synthesis and evaluation of technetium$99 \mathrm{~m}$ - and rhenium-labeled inhibitors of the prostate-specific membrane antigen (PSMA). J Med Chem. 2008;51:4504-4517.

12. Chen Y, Foss CA, Byun Y. Radiohalogenated prostate-specific membrane antigen (PSMA)-based ureas as imaging agents for prostate cancer. J Med Chem. 2008;51:7933-7943.

13. Foss CA, Mease RC, Fan H, et al. Radiolabeled small-molecule ligands for prostate-specific membrane antigen: in vivo imaging in experimental models of prostate cancer. Clin Cancer Res. 2005;11:4022-4028.

14. Pomper MG, Musachio JL, Zhang J, et al. ${ }^{11} \mathrm{C}-\mathrm{MCG}$ : synthesis, uptake selectivity, and primate PET of a probe for glutamate carboxypeptidase II (NAALADase). Mol Imaging. 2002;1:96-101.

15. Elsässer-Beile U, Reischl G, Wiehr S, et al. PET imaging of prostate cancer xenografts with a highly specific antibody against the prostate-specific membrane antigen. J Nucl Med. 2009;50:606-611.

16. Pan MH, Gao DW, Feng J, et al. Biodistributions of ${ }^{177} \mathrm{Lu}-$ and ${ }^{111} \mathrm{In}$-labeled 7E11 antibodies to prostate-specific membrane antigen in xenograft model of prostate cancer and potential use of ${ }^{111} \mathrm{In}-7 \mathrm{E} 11$ as a pre-therapeutic agent for ${ }^{177}$ Lu-7E11 radioimmunotherapy. Mol Imaging Biol. 2009;11:159-166.

17. Pandit-Taskar N, O'Donoghue JA, Morris MJ, et al. Antibody mass escalation study in patients with castration-resistant prostate cancer using ${ }^{111} \mathrm{In}-\mathrm{J} 591$ : lesion detectability and dosimetric projections for ${ }^{90} \mathrm{Y}$ radioimmunotherapy. $\mathrm{J} \mathrm{Nucl}$ Med. 2008;49:1066-1074.

18. Morris MJ, Divgi CR, Pandit-Taskar N, et al. Pilot trial of unlabeled and indium111-labeled anti-prostate-specific membrane antigen antibody J591 for castrate metastatic prostate cancer. Clin Cancer Res. 2005;11:7454-7461.

19. Lam JS, Yamashiro J, Shintaku IP, et al. Prostate stem cell antigen is overexpressed in prostate cancer metastases. Clin Cancer Res. 2005;11:2591-2596.

20. Olafsen T, Kenanova VE, Wu AM. Tunable pharmacokinetics: modifying the in vivo half-life of antibodies by directed mutagenesis of the Fc fragment. Nat Protoc. 2006;1:2048-2060.

21. Olafsen T, Gu Z, Sherman MA, et al. Targeting, imaging, and therapy using a humanized antiprostate stem cell antigen (PSCA) antibody. J Immunother. 2007;30:396-405.
22. Leyton JV, Olafsen T, Lepin EJ, et al. Humanized radioiodinated minibody for imaging of prostate stem cell antigen-expressing tumors. Clin Cancer Res. 2008; 14:7488-7496.

23. Leyton JV, Olafsen T, Sherman MA, et al. Engineered humanized diabodies for microPET imaging of prostate stem cell antigen-expressing tumors. Protein Eng Des Sel. 2009;22:209-216.

24. Parry R, Schneider D, Hudson D, et al. Identification of a novel prostate tumor target, mindin/RG-1, for antibody-based radiotherapy of prostate cancer. Cancer Res. 2005;65:8397-8405.

25. Schneider DW, Heitner T, Alicke B, et al. In vivo biodistribution, PET imaging, and tumor accumulation of $86 \mathrm{Y}-$ and ${ }^{111} \mathrm{In}$-antimindin/RG-1, engineered antibody fragments in LNCaP tumor-bearing nude mice. J Nucl Med. 2009;50: $435-443$.

26. Adams GP, Schier R, McCall AM, et al. High affinity restricts the localization and tumor penetration of single-chain fv antibody molecules. Cancer Res. 2001;61:4750-4755.

27. Ruan W, Sassoon A, An F, Simko JP, Liu B. Identification of clinically significant tumor antigens by selecting phage antibody library on tumor cells in situ using laser capture microdissection. Mol Cell Proteomics. 2006;5:23642373.

28. Roth A, Drummond DC, Conrad F, et al. Anti-CD166 single chain antibodymediated intracellular delivery of liposomal drugs to prostate cancer cells. Mol Cancer Ther. 2007;6:2737-2746.

29. An F, Drummond DC, Wilson S, et al. Targeted drug delivery to mesothelioma cells using functionally selected internalizing human single-chain antibodies. Mol Cancer Ther. 2008;7:569-578.

30. Nielsen UB, Kirpotin DB, Pickering EM, et al. Therapeutic efficacy of antiErbB2 immunoliposomes targeted by a phage antibody selected for cellular endocytosis. Biochim Biophys Acta. 2002;1591:109-118.

31. Liu B, Conrad F, Cooperberg MR, Kirpotin DB, Marks JD. Mapping tumor epitope space by direct selection of single-chain Fv antibody libraries on prostate cancer cells. Cancer Res. 2004;64:704-710.

32. Waibel R, Alberto R, Willuda J, et al. Stable one-step technetium-99m labeling of His-tagged recombinant proteins with a novel Tc(I)-carbonyl complex. Nat Biotechnol. 1999;17:897-901.

33. Bidlingmaier S, He J, Wang Y, et al. Identification of MCAM/CD146 as the target antigen of a human monoclonal antibody that recognizes both epithelioid and sarcomatoid types of mesothelioma. Cancer Res. 2009;69: 1570-1577.

34. Lindmo T, Boven E, Cuttitta F, Fedorko J, Bunn PA Jr. Determination of the immunoreactive fraction of radiolabeled monoclonal antibodies by linear extrapolation to binding at infinite antigen excess. J Immunol Methods. 1984; 72:77-89.

35. Wu AM, Chen W, Raubitschek A, et al. Tumor localization of anti-CEA singlechain Fvs: improved targeting by non-covalent dimers. Immunotechnology. 1996;2:21-36.

36. Ahlgren $\mathrm{S}$, Wållberg $\mathrm{H}$, Tran TA, et al. Targeting of HER2-expressing tumors with a site-specifically ${ }^{99 \mathrm{~m}}$ Tc-labeled recombinant affibody molecule, ZHER2:2395, with C-terminally engineered cysteine. J Nucl Med. 2009;50: 781-789.

37. Ren G, Zhang R, Liu Z, et al. A 2-helix small protein labeled with ${ }^{68} \mathrm{Ga}$ for PET imaging of HER2 expression. J Nucl Med. 2009;50:1492-1499.

38. Bidlingmaier S, Liu B. Interrogating yeast surface-displayed human proteome to identify small molecule-binding proteins. Mol Cell Proteomics. 2007;6:20122020.

39. Bidlingmaier S, Liu B. Construction and application of a yeast surface-displayed human cDNA library to identify post-translational modification-dependent protein-protein interactions. Mol Cell Proteomics. 2006;5:533-540.

40. Conrad F, Zhu X, Zhang X, et al. Human antibodies targeting cell surface antigens overexpressed by the hormone refractory metastatic prostate cancer cells: ICAM-1 is a tumor antigen that mediates prostate cancer cell invasion. J Mol Med. 2009;87:507-514. 